\title{
Theoretical Reasons for Economic Sociology
}

\author{
Robert Rogowski \\ $\mathrm{PhD}$, State University of Applied Sciences in Nowy Sacz, Poland
}

\begin{abstract}
In this paper I try to justify necessity of developing economic sociology in social sciences. In doing so, I present economic sociology as a sub-discipline. The text draws on the interdisciplinary strengths of economic sociology. The core of the article are arguments why economic sociology may be helpful to understand economic life in better way than economics does. The sociological approach, which is different from the economic approach, may be very useful to better understanding economic mechanisms, which are in fact, social mechanisms. The motivations of writing this paper is to explain that using the sociological approach to economic topics has a great research potential and should be still developed. Some economists and sociologists assume that there are separate spheres: the first one is an arena for rational economic activity (the sphere of calculation and efficiency) and the second one, the sphere of sentiment and solidarity. This is an incorrect separation. Real economy consists not only of market-mediated transactions. Economic life is always social life in which human beings participate. Reducing human nature only to economic dimension is an anthropological mistake.
\end{abstract}

Keywords: economic sociology.

JEL Classification: A14.

(C) The Author, 2017. This article is published with open access at ARMG Publishing.

\section{Introduction}

Every individual participates in a number of different social interactions. A lot of them are business deals. Because of the human nature everyone has to consume, to buy, to work, to pay taxes etc. Being entrepreneur needs society, because entrepreneurship outside the society has no reasons. Markets are social phenomena. In economic life, which is in fact social life, people are co-oriented toward expectations of the potential action of other exchange partners (competitors from both sides). (Weber, 1981: 171-72)

Some economists and sociologists assume that there are separate spheres: the first one is an arena for rational economic activity (the sphere of calculation and efficiency) and the second one, the sphere of sentiment and solidarity. Zelizer has called it "the twinned stories of separate spheres and hostile worlds" (Zelizer, 2007: 1059). I agree with Zelizer, that this is an incorrect separation. Real economy consists not only of market-mediated transactions. Economic life is always social life in which human beings participate. Reducing human nature only to economic dimension is an anthropological mistake.

I agree with A. Koźmiński's thesis, that study of economic life requires an interdisciplinary approach. According to him a very good research approach is the science linking economics and sociology (that is the economic sociology).

It is necessary to conduct empirical researches on economic facts. Unfortunately, some economists proclaim their believes based on speculation and more or less conscious assumptions. Instead of making grounded and proper methodological research in economics, we have ideological debates. Meanwhile, social and economic reality is constantly changing. The study of economic life should be based on clearly established facts. Another phenomenon is that some economists support interests of certain economical and political groups. Some of them appear in the media and present their points of view misleading and distorting the perception of economic reality. It is disadvantageous to the economy as a science and economical knowledge of individuals in the society. The researcher considers that useless and pointless discussions of representatives of the different school of economics have to be changed by return to the study of reality and facts of social and economic life. To do this interdisciplinary approach is a right direction. A. Koźmiński rightly notes that it is a need to study economic problems in an interdisciplinary perspective, and not just in the narrow terms of only one discipline. Artificial created boundaries between disciplines inhibit in realizing this idea (Koźmiński, 2016: 11-23). 
A worth methodological approach to social science is a pragmatic one. It involves using the method best suited to the research problem and not getting caught up in philosophical debates about which is the best approach. The pragmatic approach to research means that researchers therefore grant themselves the freedom to use any of the methods, techniques and procedures. Every scientific study should begin with a welldefined research problem. Then it is necessity to choose the most adequate research method and technique. Less important are the disciplines to which we classify the subject of the research. Probably it will belong to at least several disciplines, for instance economics, sociology, psychology, management, law, political science, ethics, medicine and others. The most important point is to discuss the research problem with representatives of others disciplines. It seems certain that the results of research in these different sciences is a technical and methodological problem. A good way is to arrange interdisciplinary conferences focused on the specific research problem. Meanwhile topics of the most conferences are a very too wide range.

The economical reality is multidimensional. The main participant of the economic life is a human being. The nature of a man is highly complex. We can distinguish a lot of dimensions of human nature. All they (rationality, will, emotions, materiality, spirituality, social aspects, political aspects, morality, situational factors) have some influence on behavior and life as a whole. This is why it is so difficult to understand a man, choosing a certain economic decisions, too.

The economic approach to human do not take into the consideration such aspects like norms and values, social mechanisms of groups, organizations and national and multinational macrostructure dimension. Economics, as a science, do not sufficiently considers ethics, ideologies, politics, emotions, social movements, irrational choices, lies and understatements in media, informal groups, structures of the organizations, coalitions, groups of interests etc. All these social mechanisms are important if we want to understand economical systems. (Koźmiński, 2016: 28) So, if economics is a science considering only rational choices, we are not able to properly and fully explain economic life. Moreover, we will not be able to formulate correct predictions. I agree with statement formulated by one of Polish economists G. Kołodko. He climes that economists who do not take into consideration results of other disciplines cannot understand economic reality which is always complex, not just one dimensional (Kołodko, 2008: 54).

In economic sociology social relations are combined with interests. It is important to notice, that sociological concept of interest is broader than the standard economic concept of interest.

Interests represent the primary driving force of human action, but there are also other forces like family inluence, corporations, nation state, values. People in everyday life bring together their interests into larger forces. Economic life mostly consists of cooperation. In corporations and small businesses people cooperate with suppliers, co-workers, clients, consumers, insurance companies and others. In this way social relations arise. Competing is something secondary and has an important role in economic life, too. What I want to say, is that economic life essentially consists of cooperation. Both cooperation and competing are the social and the economical processes.

I would like to mention one more phenomenon yet. In social sciences, mainly in economics, exist an interesting fact. Thousands of journals and research papers are published every year. No one can read all the publications dealing with a specific problem. Therefore there is a question of possibility of understanding by one person of one particular research complex problem. I think this is the challenge for the future of social sciences.

\section{Economic sociology as a sub-discipline}

Magnificent achievements in traditional economic sociology are the works of Weber, Sombart and Schumpeter. The economic sociology begins primarily in the result of Max Weber's work. He was a representative of the Historical School of Economics and he attempted to lay a theoretical foundation for economic sociology. Weber stressed that all economic actions should be characterized by the meaning they have for human action. According to him "Economic sociology is a science concerning itself with the interpretive understanding of social economic action and thereby with a causal explanation of its course and consequences. We shall speak of 'economic action' insofar as the acting individual attaches a subjective meaning that involves the economy to his behavior - be it overt or covert, omission or acquiescence. Economic action is 'social' insofar as its subjective meaning takes account of the behavior of others and is thereby oriented in its course" (Weber, 1978: 4). The German economic sociology developed the idea, that economics is not a 
natural science but a cultural science. The consequence is that economic should use the historical method (Swedberg, 1991: 258-259).

Because the aim of the article is not presenting history of the economic sociology as a discipline, it is worth to notice that major traditions of the discipline (German, French, United States) are presented by Swedberg in his article (Swedberg, 1991).

Economic sociology, as N.J. Smelser and R. Swedberg write in their Handbook of Economic Sociology, is "the application of the frames of reference, variables, and explanatory models of sociology to that complex of activities which is concerned with the production, distribution, exchange and consumption of scarce goods and services" (Smelser, Swedberg, 2005: 3). In other words, economic sociology is the application of the sociological perspective to economic phenomenon. The material object of the study is the same in economy as in economic sociology. The difference is in formal aspects of research, which in economy is narrower than in sociology.

Economic sociology differs from economics, which deals with economic behavior per se, for instance in economic rational choice theory is differ and focuses on the economic variables of social life. Economic sociology examines the sociological categories of economic life (social construction of the economy).

\section{Arguments}

Interactions between economy and society are the main classical area of research in economics and in sociology. In classical economics economic life is analyzed without taking into account of social context. Similarly in sociology, economics aspects of human life are not sufficiently investigated. These two shortcomings influenced the emergence and development of the economic sociology. The process of economic life almost always are social actions. Economic actions are socially situated (Partycki, 2004: 6).

In economy the fact that economic action typically consists of some kind of interactions is usually ignored. According to R. Swedberg this is because economic analyses were formalized well before there had been a sophisticated concept of social action. "Both economics and economic sociology argue that action in the economy is driven by economic interest; but while economics derives action directly and exclusively from the interest, economic sociology does not. In economic sociology an additional assumption is made that economic action is also social action, and that will significantly influence how the action unfolds. To put it differently, while economics can be said to focus on the shortest distance involved ("as the crow flies"), economic sociologists try to capture the "real" distance involved when the economic actor tries to get from A to B" (Swedberg, 2004: 7).

I have to agree with A. Koźmiński's thesis about two main fallacies in economics as a science. The first one is reductionism and the second one is universalism. Reductionism is based on the use of simplified models reducing complex phenomena to several factors. Universalism is searching for universal truths matching all cases (Koźmiński, 2016: 18).

Another wrong idea in economics is the conception of human nature. In microeconomics the economic action is made by individual assumed to have a given and stable set of preferences. All the people, in economic theory, choose from the alternative line of actions which maximizes utility. Economic actor always makes economically rational action. Meanwhile, in economic sociology there are different possible types of economic action. According to Weber economic action can be either rational, traditional or affective (emotional, desiring) (Weber, 1978, 63-68). In economics human action traditionally is rational what means the most efficient use of scarce resources. Economists tend to portray social order as a product of self interest. Economics deals only with price determination under a hypothetical regime of free competition. Economic sociology aims to focus on the ways in which noneconomic phenomena relate to the structure and functioning of the economic system. In economic sociology individual making decisions also refers to allocation within the guidelines of other values and principles, for instance such as loyalty to others, moral and religion values. Economists treat rationality as an assumption, whereas in sociology it is understood just as a variable (Smelser, Swedberg, 2005: 3). Moreover, in real life an individual action is not only oriented to another actor, but also to something that Weber terms an order. The concept of order includes such things like norms, organizations, institutions. An order is a prescription for how to act in social life to realize interests of an individual and society. Institutions, as large complexes of prescriptions for how to act, are typically backed up by law which is linked to the political order. According to Polanyi, concepts such as norms, organizations and institutions are needed in every economy to stabilize it. This can occur in three ways: 
through reciprocity (sharing), redistribution (allocation via a government) and exchange (distribution via a price-making market) (Swedberg, 2004: 9-11).

Human person has a free will, so they do not have to maximize their revenue but just can do it. For instance, entrepreneur do not have to maximize his profit, but he has to work to achieve enough profit (which satisfies him). Additionally, in real life, a human rationality is limited, so the idea that individuals always make rational (in economic sense) decisions is wrong. Rationality may be limited by the tractability of the problem, the cognitive mind limitations, time available to make decisions etc. According to H. Simon's theory of bounded rationality, people seek a satisfactory solution rather than an optimal one. His theory takes into account a reality of human nature and possibilities of a man. Economic model of optimal choice is the idealistic one (Simon, 1955). But of course, it is useful in doing some general predictions. We have to distinguish between the tendency to be rational and possibilities of being rational. Doing business does not mean that entrepreneur always makes optimal economical decisions. In fact, there are probably several possibilities of decisions helping to achieve a desired goal entrepreneur can take.

Next difference between economy and economic sociology emerges in the status of meaning in economic action. Economists tend to not take into the consideration that economic action is not only the relation between given tastes, the prices and quantities of goods and services. In reality, there is some meaning in every human action, and in economical action too. Meanings should be investigated empirically but in economy theory they are just assumptions that every human being only try to get the most utility as it is possible. (Smelser, Swedberg, 2005: 5). Weber opened up the concept of economic and social action to a cultural definition of meaning. Interpretive dimension of the concept of social action in economic sociology differentiates it from economic action (which is a single-dimension concept of meaning).

Another problem in economic analyses are tendencies to regard economic action as an exchange among equals. Again, it is assumption which is far from real life where in fact buyers and sellers have different power to influence price or output (Galbraith, 1973). So, the economic conception of power is narrower than the sociologist's notion of economic power. In sociology and let's say, in reality, it may be political power, class power or institutional power (for instance banking institution, industries, transnational corporations). Groups if interests may also sometimes enforce economic decisions of the government.

Economic behavior is not only the result of economic situation of a person. Economic choices and activities depend on the social structure conditions, too. Structural aspects of society constraints influence career decisions in ways that different people have different possibilities. For example, for a person who grows up in poverty, whose parents are not well-educated, the choice between higher education in comparative to use the social security benefits, may be different to person living in good financial conditions.

A well-known idea in economic sociology is the concept of embeddedness. It was introduced by Granovetter in 1980 and as analytical tool was used to explain that all economic actions are embedded in networks of social relations. The embeddedness expression is often understood as synonymous with "social" but it is wrong understanding because there is no analytical content of this meaning. The concept of embeddedness is useful when it is linked to network theory by which social interactions, including economic ones, can be measured (Swedberg, 2004: 12-13). Economic sociology applies sociological tools and concepts to gain a deeper understanding of organizations and the economy.

In economic sociology, markets are more social phenomena than just economical. Markets are always created by social interactions - they do not exist without people. So the law of demand and law of supply are not the same nature as for instance physics laws. They did not exist before humanity appears. This is commonly misunderstood in economics. Law of demand and law of supply are just human operational way to make economical decisions rational. They are being used to plan and predict economic activity. Actors of economical life are always human beings (and their different forms of social groups), so there are always some contexts in markets. Markets do not operate by themselves. The forms that markets take depend on the institutional arrangements that support them.

In economic approach human needs should be met only by work, market system and consumption. This is incomplete and narrow perception of reality. In fact, there are another mechanisms by which human needs are met. K. Polanyi notes that human needs can also be met by reciprocity and redistribution of state (Koźmiński, 2016: 35). What is interesting, in economics work of volunteers seems to be forgotten. Volun- 
teers' motivation for work is usually not a material one. It is worth to notice that the value of volunteer work is not included in the account national income.

The problem in economy is that there is still an assumption that the main aim of the world is economic development. It would be worth to discuss the problem of unlimited economic growth and good quality of life. Nowadays, there are numerous studies in new social science called economics of happiness.

\section{Conclusion}

My own view on the matter is that economist, who does not take into account the full truth about a man (human nature) makes a serious methodological and anthropological mistake. Scientists of different disciplines should come together in a collaborative effort in the service of humanity. Specializing in science is necessary but the problem arises when researches of different disciplines do not cooperate for better understanding the complexity of the reality. As Benedict XVI writes "Paul VI had seen clearly that among the causes of underdevelopment there is a lack of wisdom and reflection, a lack of thinking capable of formulating a guiding synthesis, for which 'a clear vision of all economic, social, cultural and spiritual aspects' is required. The excessive segmentation of knowledge, the rejection of metaphysics by the human sciences, the difficulties encountered by dialogue between science and theology are damaging not only to the development of knowledge, but also to the development of peoples, because these things make it harder to see the integral good of man in its various dimensions. The 'broadening [of] our concept of reason and its application' is indispensable if we are to succeed in adequately weighing all the elements involved in the question of development and in the solution of socio-economic problems" (Benedict, 2009: 31).

In my opinion, economic sociology offers useful tools to explain human activity in economic life. Socially based description and explanation of economic activity in sociology economy is closer to reality than economy is. All arguments considered, it seems that future of economic sociology looks interesting. Scientists representing different social disciplines should cooperate much more. One of the main problem is that social scientists are separated by their professional organizations. Therefore, more interdisciplinary research and conferences should be organized. Economic sociology can lighten understanding the economic life and can be very useful for economists.

\section{References}

1. Benedict XVI (2009). Caritas in Veritate, Encyclical Letter.

2. Galbraith, J. K. (1973). Power and the Useful Economist. American Economic Review, 63, 1-11.

3. Kołodko, G. (2008). Wędrujacy świat. Warszawa: Prószyński i S-ka.

4. Koźmiński, A. (2016). Wyobraźnia ekonomiczna. Warszawa: Poltext.

5. Partycki, S. (2004). Zarys teorii socjologii gospodarki. Lublin: TN KUL.

6. Simon, H. A. (1955). A Behavioral Model of Rational Choice. The Quarterly Journal of Economics, 69(1), 99-118.

7. Smelser, N., Swedberg, R. (2005). The Handbook of Economic Sociology. Princeton University Press.

8. Swedberg, R. (1991). Major Traditions of Economic Sociology. Annual Review of Sociology, 17, 251-276.

9. Swedberg, R. (2004). The Toolkit of Economic Sociology. New York: Cornell University.

10. Swedberg, R. (2005). Interpretive Economic Sociology: On the Relationship between Max Weber's Basic Sociological Terms and his Economic Sociology, CSES Working Paper Series, Paper \#29.

11. Weber, M. (1978). Economy and Society: An Outline of Interpretive Sociology. 2 vols. Berkeley and Los Angeles: University of California Press.

12. Weber, M. (1981). Some Categories of Interpretive Sociology. Sociological Quarterly, 22(1), 151-80.

13. Zellizer, V. A. (2007). Pasts and Futures of Economic Sociology. American Behavioral Scientists, 50(8), 1056-1069. 